\title{
Bradykinin stimulates cell proliferation through an extracellular-regulated kinase 1 and 2-dependent mechanism in breast cancer cells in primary culture
}

\author{
S Greco, M G Elia, A Muscella, S Romano, C Storelli \\ and $\mathbf{S}$ Marsigliante \\ Laboratory of Cellular Physiology, Department of Biological and Environmental Sciences and Technologies, Ecotekne, Università di Lecce, Monteroni, \\ Via Provinciale per Monteroni, 73100 Lecce, Italy \\ (Requests for offprints should be addressed to S Marsigliante; Email: santo.marsigliante@unile.it)
}

\begin{abstract}
We have previously reported that bradykinin (BK) represents an influential mitogenic agent in normal breast glandular tissue. We here investigated the mitogenic effects and the signalling pathways of BK in primary cultured human epithelial breast cells obtained from a tumour and from the histologically proven non-malignant tissue adjacent to the tumour. BK provoked cell proliferation, increase in cytosolic calcium, activation of protein kinase $\mathrm{C}(\mathrm{PKC})-\alpha,-\beta,-\delta,-\varepsilon$ and $-\eta$ and phosphorylation of the extracellular-regulated kinases 1 and 2 (ERK1/2). The following compounds blocked the proliferative effects
\end{abstract}

of BK: Hyp3-BK, a $\mathrm{B}_{2}$ receptor subtype inhibitor; U73122, a phospholipase C- $\beta$ inhibitor; GF109203X, a protein kinase C (PKC) inhibitor; and PD98059, a mitogen-activated protein kinase kinase inhibitor. Gö6976, a $\mathrm{Ca}^{2+}$-dependent PKC inhibitor, did not have any effect. In conclusion, the mitogenic effects of $\mathrm{BK}$ are retained in peritumour and tumour cells; hence, it is likely that BK has an important role in cancer endorsement and progression.

Journal of Endocrinology (2005) 186, 291-301

\section{Introduction}

Bradykinin (BK) is a kinin liberated from kininogens by the enzymatic action of kallikreins and participates in a wide range of physiological effects such as organ perfusion, systemic blood pressure, sodium and water homeostasis, regulation and maturation of growth factors and inflammation (Chen et al. 1988, Yu et al. 1998). BK exerts its action via two known receptors, namely, $B_{1}$ and $B_{2}$ receptors (Regoli \& Barabé 1980, Vavrek \& Stewart 1985, Ma et al. 1994, el-Dahr et al. 1997, Pesquero \& Bader 1998). The kallikrein-kinin system is implicated in tumourigenesis through the actions of kinins (Robert \& Gulick 1989, Maeda et al. 1999), since released kinins increase vascular blood flow and promote the supply of nutrients and oxygen to the tumour. This may be important in the processes of tumourigenesis and angiogenesis (Clements 1997, Plendl et al. 2000). BK is present in tumours of the stomach, pituitary, uterus and breast (Koshikawa et al. 1992, Jones et al. 1992, Clements \& Mukhtar 1977, Hermann et al. 1995, Rehbock et al. 1995). Breast cancer is the most common cancer in women worldwide and continues to be a major health problem (Harris et al. 1992, Henderson 1993, Henson \& Tarone 1994). The evolution of breast cancer and the relationships of genetic predispos- ing factors with somatic changes are very complicated. Genetic and hormonal factors such as BRCA1/2 (breast cancer 1, early onset gene), p53, oestrogen, progesterone, prolactin, insulin-like growth factors, epidermal growth factor (EGF) and transforming growth factor- $\beta$ (Biscardi et al. 2000, Sachdev \& Yee 2001, Wakefield et al. 2001, Blackburn \& Jerry 2002, Portier 2002, Venkitaraman 2002) are involved in the development of breast cancer and progression of the disease. In normal breast cell proliferation, a crucial role of the extracellular-regulated kinase 1 and 2 (ERK1/2) has been defined, and agonists such as angiotensin II (Ang II) and BK (Greco et al. 2002b, 2004) are able to induce proliferation through this pathway. If deregulation occurs, ERK1/2 is still crucial in determining the overall proliferation of the tumour cell by Ang II (Greco et al. 2003). In the human breast cancer EFM-192A cell line, BK has a proliferative effect mediated through the activation of the mitogen-activated protein kinase (MAPK) (Drube \& Liebmann 2000). We previously reported that in primary cultured epithelial cells, obtained from normal breasts, BK increases cell proliferation by the activation of ERK1/2 (Greco et al. 2004). Inhibitors of angiogenesis and of matrix invasion are in development as anti-cancer agents. BK antagonists are involved in the US National Cancer Institute's trials as 
drugs for non-small cell lung and prostate cancers, since they are without any evidence of harmful side-effects and, in addition, they have been shown to actively reduce the growth of a broad range of cancer cells, including the ZR-75 breast cancer cells (Stewart 2003).

We here aimed to ascertain whether BK is also a suitable candidate for the proliferative response in human primary cultured epithelial breast cancer cells. To this end, we made primary cell cultures from six cancers in order to investigate whether the BK mitogenic role is still retained in the tumour. Furthermore, the effects of BK were also studied in primary cultured epithelial breast cells obtained from the corresponding histologically proven nonmalignant tissue adjacent to the tumour in order to compare results and to specifically evaluate the responsiveness of the cell types obtained from the same patients.

\section{Materials and Methods}

\section{Materials}

RPMI 1640 medium, antibiotics, glutamine and foetal bovine serum (FBS) were purchased from Celbio (Pero, MI, Italy). Mouse monoclonal antibody for cytokeratin 19 was purchased from Chemicon International (Prodotti Gianni, MI, Italy. Protein kinase C (PKC) and ERK1/2 antibodies were purchased from Santa Cruz Biotechnology (Segrate, MI, Italy); Gö6976 and AG1478, conventional PKCs and EGFR inhibitors respectively, were obtained from Calbiochem (Milan, Italy). All others reagents were from Sigma (Milan, Italy).

\section{Primary culture of breast cancer epithelial cells}

Six breast cancer tissues and the corresponding histologically proven non-malignant tissue adjacent to the tumour (peritumoural) were obtained after total mastectomies and immediately sent to the histopathology laboratory for the histological diagnosis. All patients gave informed consent to study participation before enrollment. The study protocol was approved by the ethics committee of Lecce University in accordance with the Declaration of Helsinki. All the tumours were invasive intraductal carcinomas from postmenopausal patients who had not received any therapy before surgery. Portions of tissue were placed into transport medium and disaggregated immediately as described previously (Greco et al. 2002a). Briefly, breast tissue fragments were digested in RPMI 1640 medium containing $0.010 \mathrm{mg} / \mathrm{ml}$ insulin, $10 \%$ FBS, $1.0 \mathrm{mg} / \mathrm{ml}$ collagenase type I and $100 \mathrm{U} / \mathrm{ml}$ hyaluronidase overnight at $37^{\circ} \mathrm{C}$ on a rotary platform (200 r.p.m.). After digestion, tissue suspension was pushed through three stainless steel screens $(100,60$ and $50 \mu \mathrm{m}$ mesh size respectively) in order to obtain dispersed cell suspensions that were suspended in 20\% FBS growth medium (RPMI 1640 medium, $100 \mathrm{U} / \mathrm{ml}$ penicillin, $0.1 \mathrm{mg} / \mathrm{ml}$ streptomycin, $2.0 \mathrm{mM}$ glutamine, $0.005 \mathrm{mg} / \mathrm{ml}$ insulin, $5.0 \mathrm{ng} / \mathrm{ml} \mathrm{EGF}$, $0.5 \mu \mathrm{g} / \mathrm{ml}$ hydrocortisone, $5.0 \mu \mathrm{g} / \mathrm{ml}$ transferrin, $0.1 \mu \mathrm{M}$ isoproterenol, $0.01 \mu \mathrm{M}$ ethanolamine and $0.01 \mu \mathrm{M}$ o-phosphoetanolamine) and seeded into culture flasks.

After the first passage, cell cultures were maintained at $37^{\circ} \mathrm{C}$ in a humidified environment containing $5 \% \mathrm{CO}_{2}$ for up to seven passages in 5\% FBS growth medium to avoid fibroblast contamination. The cultured cells exhibited the characteristic features of epithelial cells, i.e. a positive immunocytochemical staining for cytokeratin 19; the contamination from fibroblasts was quantified by using anti-Vimentin antibody (Sigma), showing that their expression was lower than 5\% (data not shown).

\section{Low-density oligonucleotide microarray}

Twenty-two genes were chosen using the data in the literature and analysed using oligonucleotide probes. Probes were selected from the $3^{\prime}$ end using the public domain software ROSO (http://pbil.univ-lyon1.fr/roso/) and checked for alignment with Blast software (http:// www.ncbi.nlm.nih.gov/blast/). The criteria used to design the oligonucleotide sequences were: (1) Tm difference $\pm 5{ }^{\circ} \mathrm{C}$; (2) distance of $800-1200$ bases from the $3^{\prime}$ end; (3) contiguous single nucleotide base repeats $<4 \mathrm{nt}$; (4) potential hairpin structures $<9 \mathrm{nt} ; \quad$ (5) guanine+ cytosine content (GC) between 40 and 55\%; and (6) Blast $<70 \%$ similarity. Oligonucleotide sequences (40 mer) were extracted with a melting temperature of $72.57 \pm$ $2 \cdot 76{ }^{\circ} \mathrm{C}$ and with $46 \cdot 1 \pm 4 \cdot 47 \mathrm{GC} \%$. Oligonucleotides were synthesised and modified with a C6 amino linker by MWG Biotech Srl (Florence, Italy) and were spotted at $40 \mathrm{pmol} / \mu \mathrm{l}$ in $50 \%$ DMSO with the MicroCASTer manual arrayer (Schleicher \& Schuell BioScience, Inc., Keene, NH, USA) in duplicate on MWG epoxy slides and kept at $42{ }^{\circ} \mathrm{C}$ for $8 \mathrm{~h}$ before hybridisation.

Breast cells were grown in complete medium with 5\% FBS for $24 \mathrm{~h}$ and then total RNAs were extracted by the RNA extraction kit (Promega, Madison, WI, USA). The RNAs were used for the amino-allyl dUTP labelling reaction (Randolph \& Waggoner 1997). Briefly, $10 \mu \mathrm{g}$ total RNA was mixed with $0.5 \mu \mathrm{g} / \mu \mathrm{l}$ oligo (dT) $12-18$ primer (Invitrogen, San Giovanni Milanese, MI, Italy) and RNase-free water to $18 \cdot 2 \mu \mathrm{l}$ and incubated at $70{ }^{\circ} \mathrm{C}$ for $10 \mathrm{~min}$, then snap-frozen in ice for $30 \mathrm{~s}$ and $6 \mu \mathrm{l} 5 \times$ Superscript buffer (Invitrogen), $3 \mu \mathrm{l} 0 \cdot 1 \mathrm{M}$ 1,4-dithio-DLthreitol, $0.6 \mu \mathrm{l} 50 \times$ amino-allyl acid (aa)-dNTP mix (final concentration: $25 \mathrm{mM}$ dATP, $25 \mathrm{mM}$ dCTP, $25 \mathrm{mM}$ dGTP, $15 \mathrm{mM}$ dTTP and $10 \mathrm{mM}$ aa-dUTP) and $2 \cdot 0 \mu \mathrm{l}$ Superscript II RT (200 U/ $\mu$ l) (Invitrogen) were added to the mixture. After incubation at $42^{\circ} \mathrm{C}$ for $2 \mathrm{~h}$, the RNA was hydrolysed with $10 \mu \mathrm{l} 1 \mathrm{M} \mathrm{NaOH}$ and $10 \mu \mathrm{l}$ $0.5 \mathrm{M}$ EDTA at $65^{\circ} \mathrm{C}$ for $15 \mathrm{~min}$; then $10 \mu \mathrm{l} 1 \mathrm{M} \mathrm{HCl}$ was added to neutralise the $\mathrm{pH}$. The unincorporated aa-dNTPs and free amines were removed with Genomed 
JETquick DNA Clean-up Spin kit (Celbio). The aacDNA was speed vacuum dried and resuspended in $4.5 \mu \mathrm{l}$ $0 \cdot 1 \mathrm{M} \mathrm{Na}_{2} \mathrm{CO}_{3}$ for Cy3 Dye Ester coupling (Amersham Bioscience Ltd, Little Chalfont, Bucks, UK). Prehybridisation was carried out using $1 \times$ SSC with $0 \cdot 1 \%$ SDS for 1 min with vigorous agitation; then the slides were washed. The speed vacuum dried Cy3-labelled aa-cDNA dissolved in $30 \mu \mathrm{l}$ hybridisation solution $(50 \%$ formamide, $1 \times$ SSC and $0 \cdot 1 \%$ SDS) was used for hybridisation. The slides were covered with a sterile coverglass and incubated at $42{ }^{\circ} \mathrm{C}$ for $15-18 \mathrm{~h}$ in microarray hybridisation chambers (Camlab, Cambridge, Cambs, UK). The slides were then washed in $1 \times \mathrm{SSC}, 0 \cdot 2 \% \mathrm{SDS}$, then in $0 \cdot 1 \times$ SSC and $0 \cdot 2 \%$ SDS and finally in $0 \cdot 1 \%$ SSC and centrifuged in a Falcon tube at $800 \mathrm{~g}$ for $5 \mathrm{~min}$ to dry. Slides were analysed by the Affymetrix 428 laser scanner (MWG Biotech Srl) and Cy3 fluorescence was measured at $532 \mathrm{~nm}$; spot fluorescences were converted in 8 bit images and image analysis with intensities measurements were obtained by the Eisen's free software ScanAlyze (eisen@genome.stanford.edu).

\section{Enzyme immunoassay (EIA) of oestrogen and progesterone receptors (ER and $P g R$ )}

ER EIA and PgR EIA assays (Abbott, Chicago, IL, USA) were carried out in accordance with the manufacturer's instructions.

\section{Measurement of intracellular $\mathrm{Ca}^{2+}\left[\mathrm{Ca}^{2+}\right]_{i}$}

Serum-starved breast cells were loaded with $5 \mu \mathrm{M}$ Fura 2-AM for $45 \mathrm{~min}$ at $37^{\circ} \mathrm{C}$ in HEPES-buffered KrebsRinger solution (KRH; $140 \mathrm{mM} \mathrm{NaCl}, 5.0 \mathrm{mM} \mathrm{KCl}$, $1.0 \mathrm{mM} \mathrm{MgCl}-{ }_{2}, 2.0 \mathrm{mM} \mathrm{CaCl}_{2}, 6.0 \mathrm{mM}$ glucose and $10 \mathrm{mM}$ HEPES, $\mathrm{pH} 7 \cdot 4$ ) containing $0 \cdot 2 \%$ Pluronic F-127 (Molecular Probes, Leiden, The Netherlands) and 0.1\% bovine serum albumin (BSA) (Greco et al. 2002a). Loaded cells were washed and $7 \times 10^{6}$ cells $/ \mathrm{ml}$ were used for fluorimetric measurement using the spectrofluorometer JASCO FP 750 (Jasco Corporation, Tokyo, Japan). Excitation monochromators were set at 340 and $380 \mathrm{~nm}$, with a chopper interval of $0.5 \mathrm{~s}$, and the emission monochromator was set at $510 \mathrm{~nm} .\left[\mathrm{Ca}^{2+}\right]_{\mathrm{i}}$ was calculated according to the equation of Grynkiewicz et al. (1985), using the software Spectra Manager provided by Jasco. The basal levels of $\left[\mathrm{Ca}^{2+}\right]_{i}$ and the maximal increase evoked by agonists were calculated according to the formula: $\left[\mathrm{Ca}^{2+}\right]_{\mathrm{i}}=K_{\mathrm{d}}\left[\left(\mathrm{R}-\mathrm{R}_{\min }\right) /\left(\mathrm{R}_{\max }-\mathrm{R}\right)\right]\left(\mathrm{Sf}_{2} / \mathrm{Sb}_{2}\right)$ where $R_{\max }$ and $R_{\min }$ values were determined by inclusion of $20 \mu \mathrm{l}$ Triton X-100 (0.01\% final concentration) and $20 \mu \mathrm{l}$ EGTA ( $5 \mathrm{mM}$ final concentration) respectively and $\mathrm{R}$ is the ratio of fluorescence intensities at excitation wavelengths 340 and $380 \mathrm{~nm} ; \mathrm{Sf}_{2}$ and $\mathrm{Sb}_{2}$ are the fluorescence proportionality coefficients obtained at $380 \mathrm{~nm}$ under $\mathrm{R}_{\min }$ and $\mathrm{R}_{\max }$ conditions respectively.
Proliferation assay by cell count

Breast cells were seeded at a density of $1 \times 10^{4}$ cells/well in 96-well plates in RPMI growth medium with 5\% FBS and incubated overnight at $37^{\circ} \mathrm{C}$ in a humidified environment containing $5 \% \mathrm{CO}_{2}$ to allow adherence. The medium was changed to FBS-free growth medium for $18 \mathrm{~h}$ to induce quiescence. Agonists and inhibitors were diluted in FBS-free growth medium. Cells were seeded at $2.5 \times 10^{4}$ cells/well on 24-well plates, and cells were counted in a Burker cell chamber (Sigma) $24 \mathrm{~h}$ after treatment.

\section{Immunoblot analysis}

Cells in flasks were incubated with agonist and/or inhibitors in RPMI medium without FBS for the required periods at $37^{\circ} \mathrm{C}$. The stimulation was stopped by transferring the flasks onto ice. The cells were extracted with lysis buffer $(50 \mathrm{mM}$ Tris/ $\mathrm{HCl}, \mathrm{pH} 7 \cdot 5,5 \mathrm{mM}$ EDTA, $2 \mathrm{mM}$ EGTA, $1 \mathrm{mM}$ phenylmethylsulfonyl fluoride, $1 \mathrm{mM}$ dithiothreitol, $0 \cdot 25 \mathrm{M}$ sucrose, $10 \mu \mathrm{g} / \mathrm{ml}$ aprotinin and $10 \mu \mathrm{g} / \mathrm{ml}$ leupeptin) and sonicated on ice $(3 \times 10 \mathrm{~s}$ cycles). The mixture was centrifuged for $10 \mathrm{~min}$ at $800 \mathrm{~g}$ and the supernatant was saved and centrifuged at $100000 \mathrm{~g}$ for $1 \mathrm{~h}$; the supernatant was taken as the cytosol fraction. The pellet was resuspended in lysis buffer plus $1 \%$ Triton X-100 and centrifuged as before; the supernatant was collected as the membrane fraction. Cellular lysates were used to quantify the ERK1/2 phosphorylation; cytosols and membrane fractions were collected for detecting PKC isozyme activation. We evaluated the $\mathrm{Na}^{+} / \mathrm{K}^{+}-$ ATPase activity using a coupled enzyme assay method (Norby 1988) to determine the purity of the cell compartment fractions used for immunoblotting. The enrichment factors (enzyme activities of final purified membrane pellet and cytosol compared with those of the initial homogenate) were $29 \cdot 1 \pm 3 \cdot 2$ and not determined (ND) and $35 \pm 2 \cdot 2$ and ND, in peritumour and tumour cells respectively (data not shown). An equal amount of protein was solubilised in sample buffer by boiling for $5 \mathrm{~min}$ and subjected to $10 \%$ SDS-PAGE followed by electrotransfer onto a polyvinylidene difluoride membrane (Amersham Pharmacia Biotech, Amersham, Bucks, UK). We used the rabbit antibodies against PKC isozymes and the monoclonal mouse antibody anti-phosphorylated ERK1/2. Antibody anti-PKC- $\alpha$ was diluted 1:5000, while the other anti-PKC antibodies were diluted 1:2000 and the antiphosphorylated ERK1/2 1:500. The filter was incubated with the appropriate primary antibody and then with peroxidase-conjugated secondary antibodies diluted 1:10 000. Equal protein loading was confirmed with duplicate blots probed with antiserum against total ERK1/2 (Promega). Proteins were detected using the enhanced chemiluminescence ECL (Amersham Bioscience Ltd). The intensity of the bands was quantified by 
Table 1 Description and relative intensity folds of the low-density oligo microarray

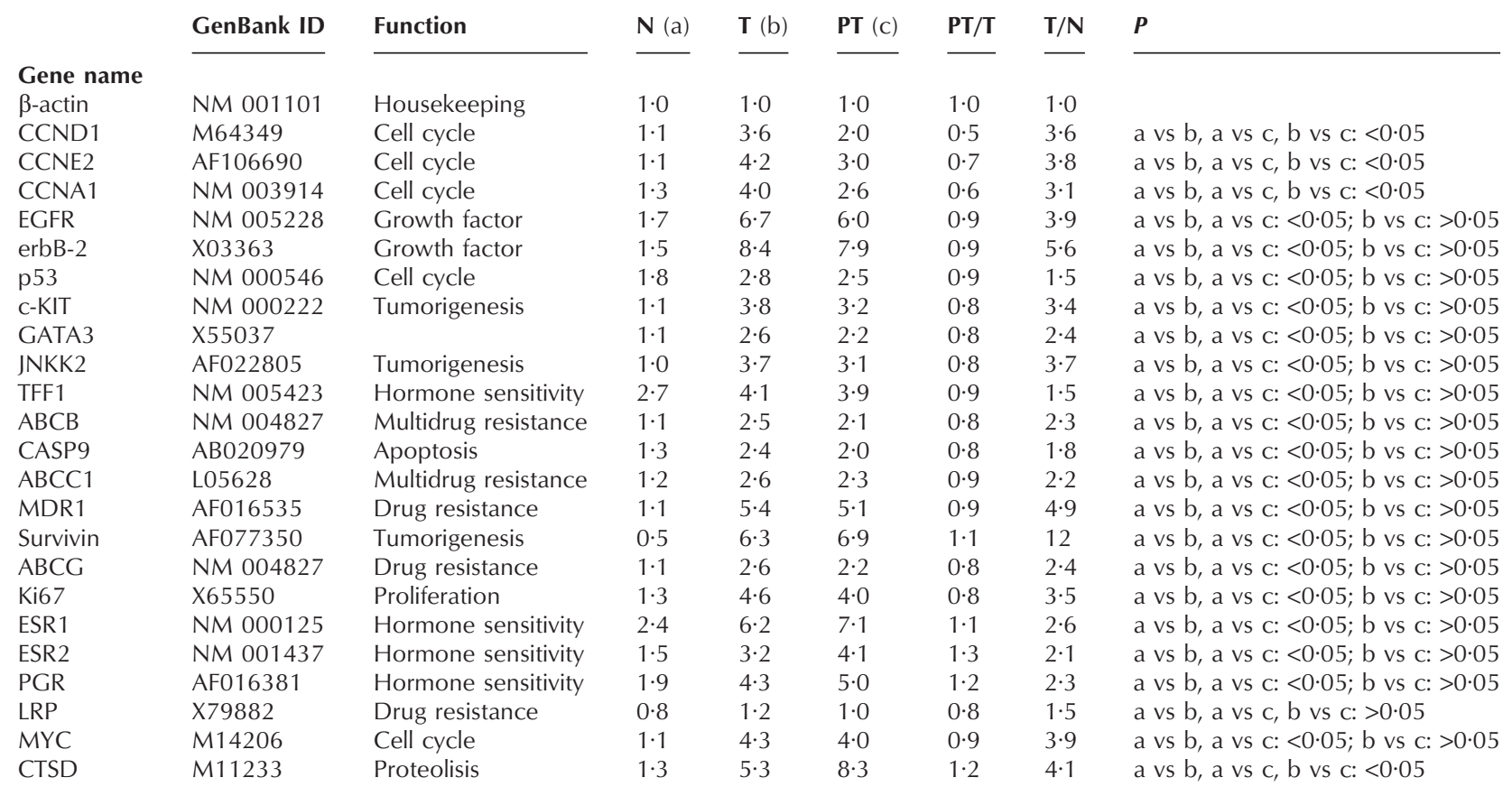

Relative fold (median intensity of each gene/median intensity of $\beta$-actin) in N, cultured peritumoural breast cells; T, cultured tumoural breast cells; PT, primary tumour fragments; PT/T and T/N, fold between the intensities of each measured gene. $P$, statistical significance by Student's $t$-test.

scanning densitometry using the NIH Image 1.62 software (NIH, Bethesda, MD, USA).

\section{Statistics}

Experimental points represent the means \pm S.D. of three replicates. Statistical analysis was carried out using Student's $t$-test for unpaired samples and ANOVA with the Fisher's PLSD test. $P<0 \cdot 05$ was chosen as the level of significance.

\section{Results}

Since (1) ER and PgR concentrations, (2) specific markers of epithelial origin and (3) BK-induced $\left[\mathrm{Ca}^{2+}\right]_{i}$ increase did not change significantly until the fourth culture passages (data not shown), we used, for all the experiments shown herein, cultured breast epithelial cells at passages two to three.

\section{Characterisation of tumoural breast epithelial cells in primary culture}

The tumoural origin of cell cultures was assessed by low-density oligonucleotide microarrays performed in primary tumour fragments and in the resultant cultured cells.
The glass slides for low-density oligonucleotide microarrays were spotted with 40 mer oligonucleotides of 23 genes, covering cell cycle regulation, ER and $\mathrm{PgR}$, multidrug resistance and metastatic/invasive phenotyping, and $\beta$-actin as the housekeeping gene (Table 1 ). The fluorescence of each spot was normalised against $\beta$-actin and the relative folds for cultured tumour cells and primary tumours are shown. Primary tumours and resultant cultured cells showed a similar gene pattern for most of the genes $(P>0 \cdot 05$, Student's $t$-test), except for the cathepsin $\mathrm{D}$ and the cyclin genes $(P<0 \cdot 05$, Student's $t$-test) (Table 1). The gene expression pattern of cultured tumour cells was then compared with that of the cultured peritumoural cells. Sixteen out of the 22 genes were significantly overexpressed in cancer compared with peritumour cells $(P<0 \cdot 05$, Student's $t$-test) (Table 1$)$.

$\mathrm{ER}$ and PgR concentrations were measured in cytosols obtained from cultured cells and from primary tumours fragments by EIA. No differences in ER and PgR concentrations between tumoural-derived cells and primary tumour fragments were obtained $(P>0 \cdot 05$, Student's $t$-test), whilst significant differences were found between primary tumour (or tumour) cells and the peritumourderived cells $(P<0 \cdot 05$ for both, Student's $t$-test) (Table 2$)$.

Cultured tumoural and peritumoural cells also had a different time-course proliferation curve and a different $\mathrm{PKC}$ isozyme expression. Cell proliferation rate was evalu- 
Table 2 ER and PgR concentrations in cytosols from primary tumours (PT), tumoral (T) and peritumoural (N)-derived cell cultures

\begin{tabular}{|c|c|c|c|c|}
\hline & PT (a) & $\mathbf{T}(b)$ & $\mathbf{N}(c)$ & $\boldsymbol{P}$ \\
\hline ER (fmol/mg protein) & $236 \pm 12$ & $289 \pm 21$ & $67 \pm 8$ & $a$ vs $b:>0.05 ; a$ vs $c, b$ vs $c:<0.05$ \\
\hline $\mathrm{PgR}$ (fmol/mg protein) & $122 \pm 10$ & $156 \pm 21$ & $33 \pm 10$ & $a$ vs $b:>0.05 ; a$ vs $c, b$ vs $c:<0.05$ \\
\hline
\end{tabular}

ated by cell counting starting from $2.5 \times 10^{4}$ seeded cells/well in complete growth medium at 24,48 and $72 \mathrm{~h}$ (Fig. 1A). Results indicate that tumour cells had a higher proliferation rate than peritumour cells $(P<0 \cdot 0001$, ANOVA). Finally, the expression of eight PKC isozymes $(\mathrm{PKC}-\alpha,-\beta,-\delta,-\varepsilon,-\eta,-1,-\vartheta$ and $-\zeta$ ) was investigated in crude cell lysates by SDS-PAGE and Western blotting analysis (Fig. 1B). All the isozymes studied were present in cultured breast cells, with the expression in tumour higher than in peritumour cells.

These data indicated that tumour-derived epithelial cells retained some biological features of the source primary tumours and that tumour and peritumour cells obtained from the same patient were different.
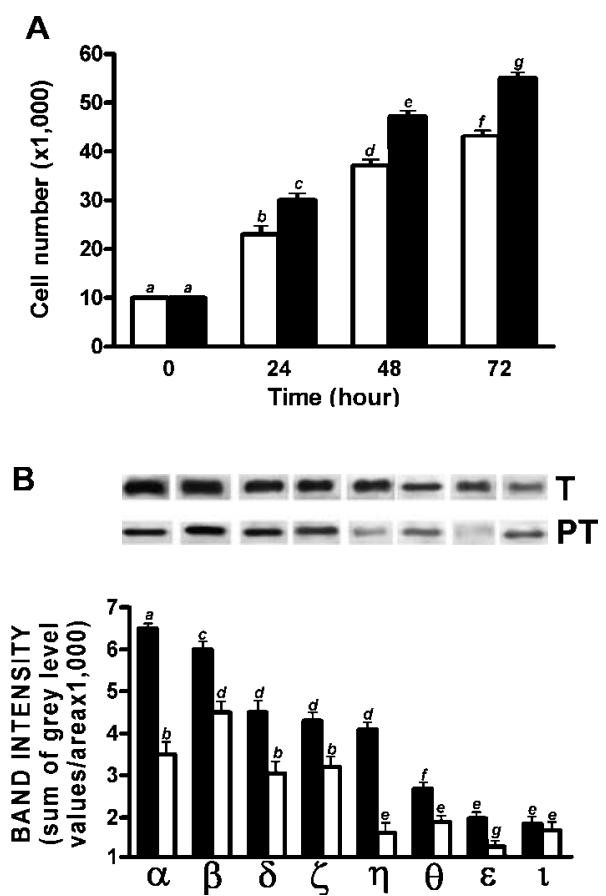

Figure 1 (A) Cell proliferation measured by cell count in tumour (solid bars) and peritumour (open bars) cells in complete growth medium at 24, 48 and $72 \mathrm{~h}$. The data are means \pm S.D. of four different experiments run in eight replicates and are presented as cell number. (B) Expression of PKC isozymes evaluated in tumour and peritumour crude cell lysates by SDS-PAGE and Western blotting analysis in samples obtained from six breasts.

Densitometry analysis of bands are also represented as histograms for tumour (solid bars) and peritumour (open bars). Different letters indicate statistical differences by Fisher's PLSD test.
We also evaluated the time-course proliferation curve, the PKC isozyme expression, ER and PgR concentrations and the gene pattern in cell culture extracts obtained from breast reductions (normal samples) used in a previous study (Greco et al. 2004). The results showed no statistically significant differences between normal and peritumoural samples (data not shown), further indicating the noncancerous origin of the cultured peritumour cells.

\section{$B K$ stimulates the proliferation of breast epithelial cells}

Cells were stimulated with increasing concentrations of BK $(0,0 \cdot 001,0 \cdot 01,0 \cdot 1,1 \cdot 0$ and $10 \mu \mathrm{M})$ and it was found that BK stimulated the $24-\mathrm{h}$ cell proliferation in a dosedependent manner, starting at $0 \cdot 001$ and reaching the maximal level at $1 \cdot 0 \mu \mathrm{M}$ BK $(P<0 \cdot 0001$, ANOVA $)$. The effect of BK was higher in tumour than in peritumour cells $(P<0 \cdot 001$, Student's $t$-test) (Fig. 2).

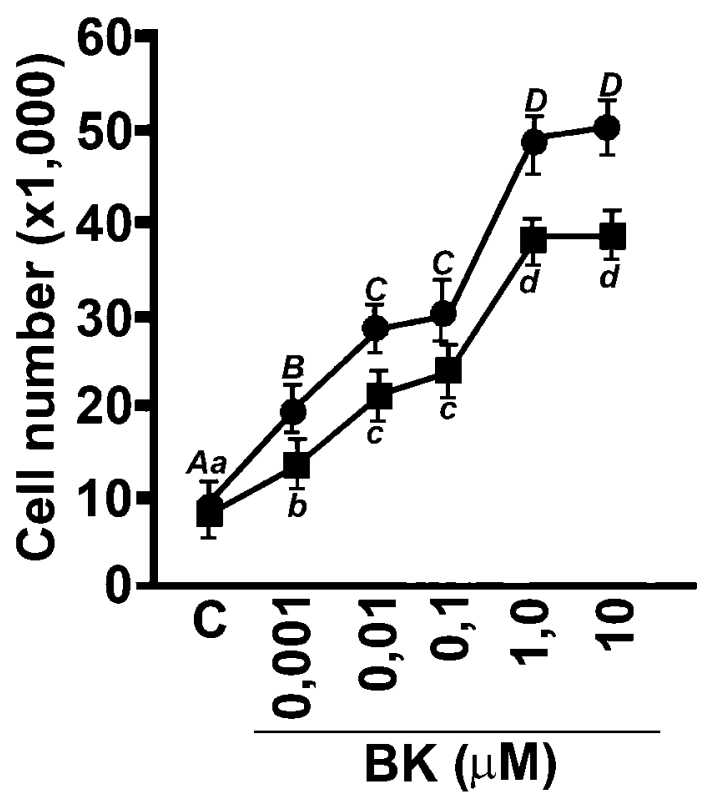

Figure 2 Serum-starved cells were incubated with increasing concentrations of BK for $24 \mathrm{~h}$. Cell proliferation was measured by cell count and results were compared with control (C), cells incubated in medium only. The data are means \pm S.D. of four different experiments run in eight replicates and are presented as cell number. Different letters indicate statistical differences by Fisher's PLSD test. 
A

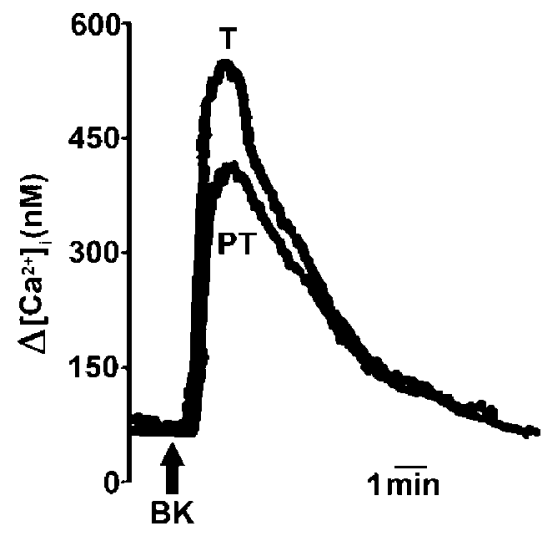

B

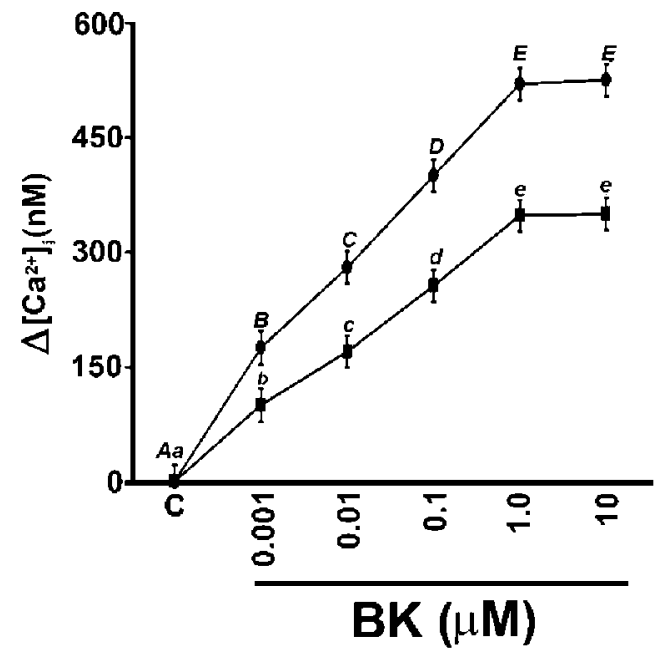

Figure 3 (A) Effect of $1 \mu \mathrm{M} \mathrm{BK}$ on $\left[\mathrm{Ca}^{2+}\right]_{\mathrm{i}}$ in tumour (T) and peritumour (PT) cells in the presence of extracellular $\mathrm{Ca}^{2+}$. The arrow indicates the time-point at which BK was added. (B) Dose-dependent response following stimulation of serum-starved tumour (circles) and peritumour (squares) cells with 0 , $0 \cdot 001,0 \cdot 01,0 \cdot 1,1$ and $10 \mu \mathrm{M} \mathrm{BK} . \Delta\left[\mathrm{Ca}^{2+}\right]_{\mathrm{i}}$ indicates the $\left[\mathrm{Ca}^{2+}\right]_{\mathrm{i}}$ concentration above the basal level. Different letters indicate statistical differences by Fisher's PLSD test. Results are representative of triplicate cell cultures from six different patients.

$B K$ mediates changes in $\left[\mathrm{Ca}^{2+}\right]_{i}$

$\mathrm{Ca}^{2+}$ mediates the expression of immediate early genes involved in cell proliferation (Ransone \& Verma 1990). The effects of $\mathrm{BK}$ on $\left[\mathrm{Ca}^{2+}\right]_{\mathrm{i}}$ were evaluated in tumour and peritumour cells. The resting $\left[\mathrm{Ca}^{2+}\right]_{\mathrm{i}}$ was $96.5 \pm 11$ and $92 \pm 12 \mathrm{nM}$ in tumour and peritumour cells respectively ( $n=8 ; P>0.05$, Student's $t$-test). The $\left[\mathrm{Ca}^{2+}\right]_{\mathrm{i}}$ response to BK was similar in shape in both cell types: BK caused an increase in $\left[\mathrm{Ca}^{2+}\right]_{i}$, in a dose-dependent manner, showing maximal effect at $1 \cdot 0 \mu \mathrm{M}$ BK. BK at $1 \mu \mathrm{M}$ induced a $\left[\mathrm{Ca}^{2+}\right]_{\mathrm{i}}$ increase with a $10-15$ s delay to a peak of $448 \pm 53 \mathrm{nM}$ above resting level in peritumour and to a peak of $600 \pm 48$ in tumour cells $(P<0 \cdot 01$ for both cell types, Student's $t$-test) (Fig. 3).

The phospholipase C (PLC) $\beta$ activity was inhibited by incubating serum-starved cells for 45 min with $1.0 \mu \mathrm{M}$ U73122, a specific PLC- $\beta$ inhibitor; cells were then stimulated with $1 \cdot 0 \mu \mathrm{M}$ BK for $24 \mathrm{~h}$. U73122 significantly reduced the BK-induced proliferation in both cells $(P<0 \cdot 0005$ for both cell types, Student's $t$-test) (Fig. 4), indicating a role of phospholipid hydrolysis in this process.

Serum-starved cells were pretreated for $45 \mathrm{~min}$ with $10 \mu \mathrm{M}$ of either $\mathrm{B}_{2}$ or $\mathrm{B}-{ }_{1}$ inhibitor, Hyp3-BK (B2-I) and Lys (des-arg-leu)-BK (B1-I) respectively, and the $24-\mathrm{h}$ proliferation induced by $1 \cdot 0 \mu \mathrm{M}$ BK was assessed. In the presence of $\mathrm{B}_{2}$ inhibitor, $\mathrm{BK}$-induced cell proliferation was completely blocked $(P<0 \cdot 0005$ for both cell types, Student's $t$-test), whilst Lys (des-arg-leu)-BK did not have any effect $(P>0.05$ for both cell types, Student's $t$-test)
(Fig. 4). These results indicated that BK leads to cell proliferation through $\mathrm{B}_{2}$ receptor activation.

\section{$B K$ activates $P K C$ isozymes}

The effects of BK on PKC isozymes were studied by stimulating serum-starved cells with $1.0 \mu \mathrm{M}$ BK for 1 , 5, 25 and $60 \mathrm{~min}$. SDS-PAGE-separated cytosol and membrane proteins were immunoblotted using specific antibodies to PKC- $\alpha,-\beta,-\delta,-\varepsilon,-\eta,-1,-\vartheta$ and $-\zeta$ isozymes. All the isozymes were expressed, but only the

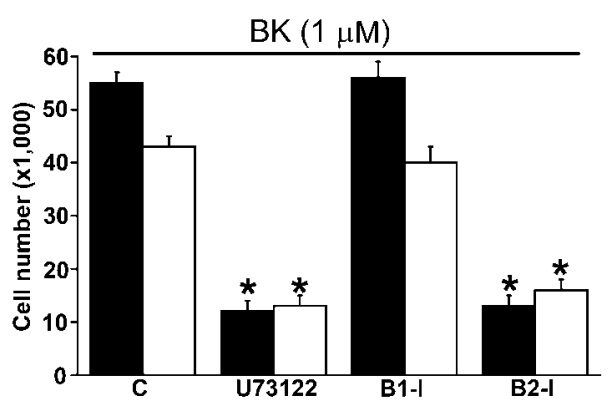

Figure 4 Serum-starved tumour (solid bars) and peritumour (open bars) cells were preincubated for 45 min with $1.0 \mu \mathrm{M}$ U73122 or 1.0 $\mu \mathrm{M}$ Hyp3-BK (B2-I) or Lys (des-arg-leu)-BK (B1-I) and then stimulated with $1 \cdot 0 \mu \mathrm{M}$ BK. Cell proliferation was measured by cell count and results were compared with cells incubated with BK only (C). The asterisks indicate statistical significance (by Student's t-test) compared with control cells treated with BK only. 

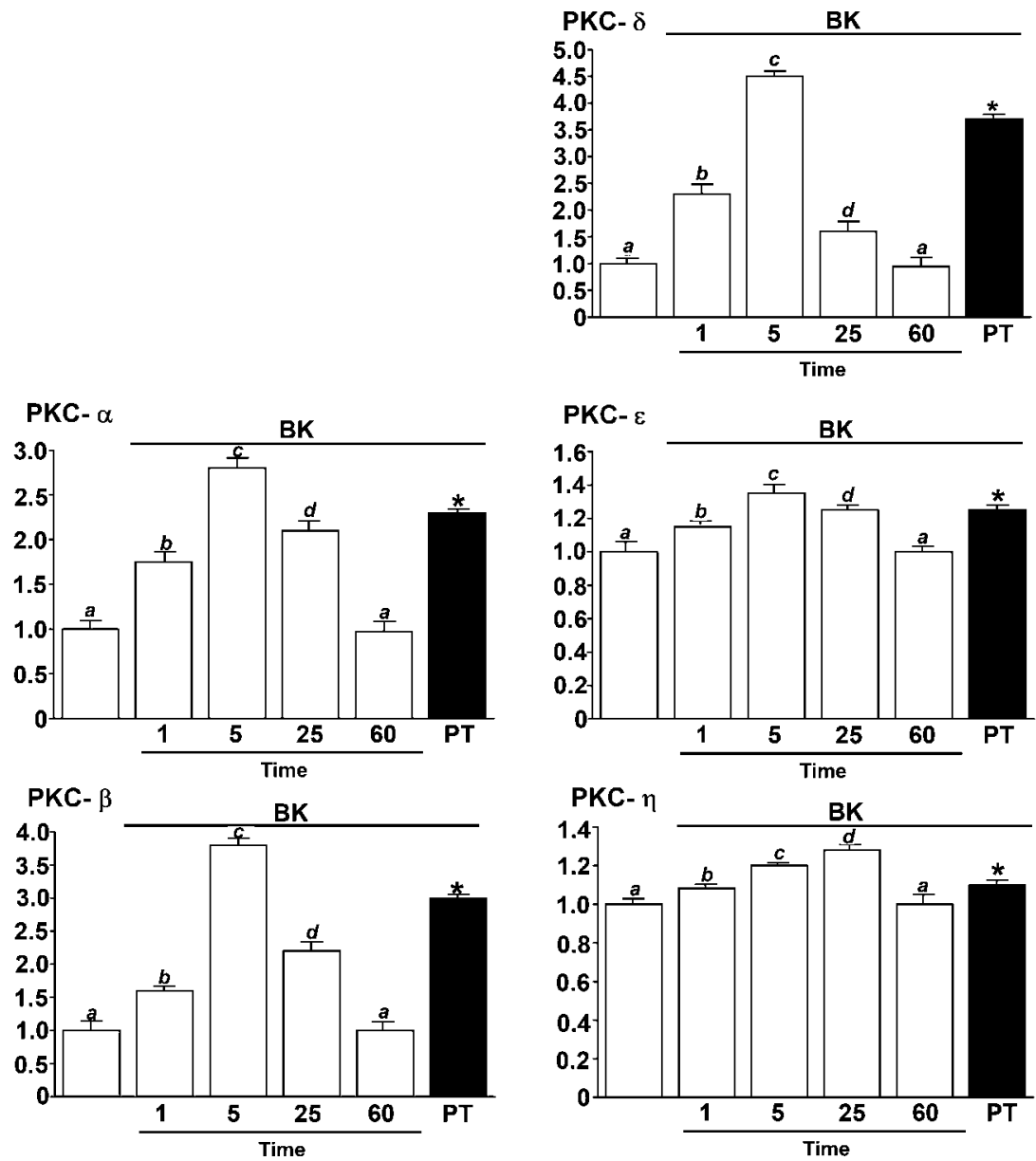

Figure 5 Fold translocation of PKC isozymes provoked by $1.0 \mu \mathrm{M} \mathrm{BK}$ at various incubation times (cancer cells; time in min) and at 5 min (peritumour cells (PT; solid bars)). PKC isoforms from control cells were considered to be $1 \cdot 0$-fold activated. Different letters indicate statistical differences by Fisher's PLSD test. The asterisks indicate statistical significance (by Student's $t$-test) between 5 min (25 min for PKC- $\eta$ ) translocation in tumour and peritumour cells.

conventional PKC- $\alpha$ and $-\beta$ and the novel PKC- $\delta,-\varepsilon$ and $-\eta$ isozymes translocated from the cytosol to the membrane. The maximal effects were obtained at $5 \mathrm{~min}$ for PKC $-\alpha,-\beta,-\delta$ and $-\varepsilon$, and at 25 min for PKC- $\eta$ in both cell types (Fig. 5) with higher translocations in tumour than in peritumour cells $(P<0 \cdot 001$ for PKC $-\alpha,-\beta$ and $-\delta$ and $P<0 \cdot 01$ for PKC- $\varepsilon$ and $-\eta$, Student's $t$-test) (Fig. 5).

\section{Novel PKC isozymes have a role in BK-dependent cell} proliferation

Serum-starved cells were incubated for 45 min with $0 \cdot 1$ and 1.0 $\mu \mathrm{M}$ Gö6976, a $\mathrm{Ca}^{2+}$-dependent PKC isozyme inhibitor, or with GF109203X, an inhibitor of all PKCs, before stimulation for $24 \mathrm{~h}$ with $1.0 \mu \mathrm{M}$ BK. Figure 6 shows that Gö6976 did not affect the mitogenic effect of

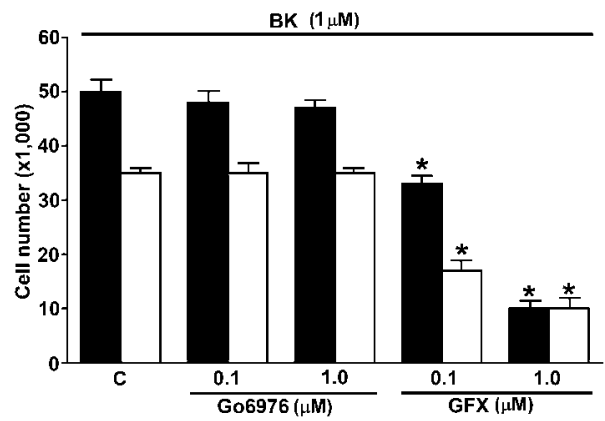

Figure 6 Tumour (solid bars) and peritumour (open bars) serum-starved cells were treated with $0 \cdot 1$ and $1 \cdot 0 \mu \mathrm{M}$ Gö6976 or GF109203X (GFX) for $45 \mathrm{~min}$ and then stimulated for $24 \mathrm{~h}$ with $1 \cdot 0 \mu \mathrm{M}$ BK. Cell proliferation was measured by cell count and results were compared with cells incubated with BK only $(\mathrm{C})$. The data are means \pm S.D. of four different experiments run in eight replicates. The asterisks indicate statistical significance (by Student's t-test) compared with control cells treated with BK only. 

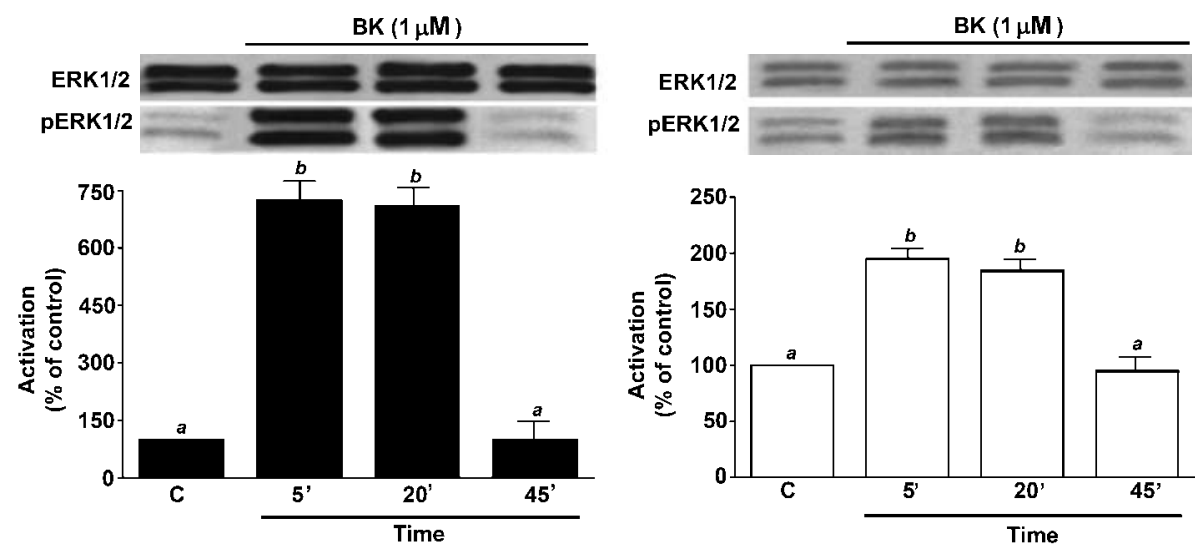

Figure 7 (A) Tumour and (B) peritumour breast cells were treated without or with $1.0 \mu \mathrm{M}$ BK for 5, 20 and $45 \mathrm{~min}$. Cell lysates were subjected to SDS-PAGE and probed with total ERK $1 / 2$ or anti-phospho-ERK1/2 (pERK1/2). Representative autoradiographs are shown and results from densitometry are expressed as the percentage ratio over cells cultured in serum-free medium only (C). Different letters indicate statistical differences by Fisher's PLSD test.

BK, either in tumour or in peritumour (Fig. 6) cells $(P>0.05$ for both cell types, Student's $t$-test $)$. On the contrary, GF109203X inhibited the mitogenic effect of BK in both cells (Fig. 6) $(P<0 \cdot 0005$ for both cell types, Student's $t$-test), indicating that novel PKC isozymes participate in the effects of BK.

\section{$B K$ activates ERK1/2 and its role in cell proliferation}

Serum-starved cells were treated with $1.0 \mu \mathrm{M}$ BK for 5 , 20 and $45 \mathrm{~min}$, and cell lysates were blotted and incubated with anti-phospho-ERK1/2 antibody. Figure 7 shows that BK induces phosphorylation of ERK1/2 $(P<0 \cdot 0005$, ANOVA), with phosphorylation higher in tumour than in peritumour cells $(P<0 \cdot 005$, Student's $t$-test).

Serum-starved cells were treated for $45 \mathrm{~min}$ with increasing concentrations $(0 \cdot 01,1 \cdot 0$ and $30 \mu \mathrm{M})$ of PD98059, an inhibitor of the mitogen-activated protein kinase kinases (MEK) upstream enzyme of the MAPK cascade (Alessi et al. 1995), before stimulation for $5 \mathrm{~min}$ with 1.0 $\mu \mathrm{M}$ BK. PD98059 had a dose-dependent inhibitory effect on BK-mediated cell proliferation in both cell types $(P<0.001$ for both cell types, ANOVA) (Fig. 8), suggesting that MEK is required for the proliferative effect of BK.

\section{Discussion}

We have recently shown a role for BK in the proliferation of the primary cultured human epithelial breast cells (Greco et al. 2004), which is mediated by the activation of MAPK. Here we have shown that BK also retains a similar behaviour in tumoural-derived cell cultures, more relevant than in peritumoural-derived cells. The complexity of obtaining a tumoural cell culture from primary tumours has prompted us to investigate if cells after culture manipulation still retain the same tumoural characteristics normally shown in primary tumours. With this in mind, we compared the expression pattern of some genes of relevance in breast cancer, e.g. ER, PgR, EGF receptor, ErbB-2 and Survivin. We found that tumoural-derived cells and primary tumours have a similar gene expression pattern evaluated by 'low-density' oligonucleotide microarray, indicating that cells in cultures retain the original tumoural characteristics (Table 1). Moreover, the overall different gene pattern between tumouraland peritumoural-derived cells indicated that there was not a cell contamination.

That BK is a growth factor for breast epithelial cells is of relevance, since BK (and prostaglandin $\mathrm{I}_{2}$ ) is one of the

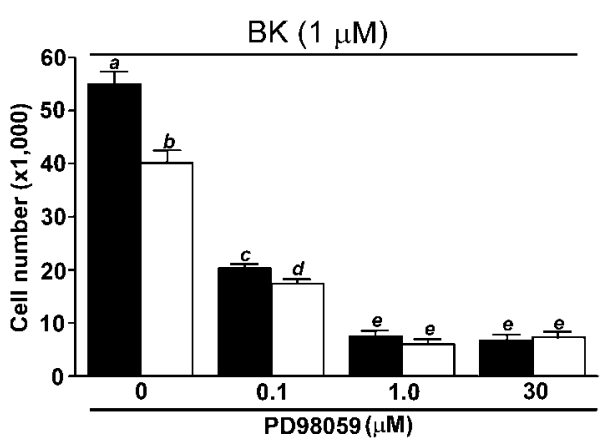

Figure 8 Tumour (solid bars) and peritumour (open bars) serum-starved cells were treated with increasing concentrations of PD98059, before treatment for 5 min with $1.0 \mu \mathrm{M}$ BK. Cell proliferation was measured by cell count and results were compared with control (C) cells incubated in medium only. Different letters indicate statistical differences by Fisher's PLSD test. 
major mediators of the initial acute phase of inflammation and the breast may develop mastitis, during lactation and at any age in relation to congenital lesions such as duct ectasia, chronic disseminated infections, or during granulomatous, autoimmune or malignant processes (Michie et al. 2003). In addition, regular use of non-steroidal anti-inflammatory drugs may have a chemopreventive effect against the development of breast cancer (Harris et al. 2003). The data shown herein regarding the overresponsiveness of breast cancer cells to BK is important inasmuch as it points to BK as an essential extracellular factor for the maintenance of the tumorigenic growth.

The progression from normal breast epithelium to breast cancer is a complex multistep process resulting from the uncoupling of the systems controlling cell proliferation and differentiation, thus leading to extensive cellular growth. Research in the human breast field regarding the control of proliferation has stressed the functional implication of oestrogens and progesterone, EGF, insulin-like growth factor, fibroblast growth factor, nerve growth factor (Ethier 1995, Descamps et al. 1998, Xing \& Imagawa 1999, Nurcombe et al. 2000, Dupont \& Le Roith 2001) and, more recently, Ang II (Greco et al. 2002b, 2003). Relationships between the physiology of the epithelial breast cell and the components of the kallikrein-BK system are poorly defined.

This study has explored for the first time the mitogenic effects of BK in primary cultured epithelial breast cells obtained from six cancerous human breasts. These mitogenic effects were compared with those achieved in primary cultured epithelial breast cells obtained from corresponding histologically proven non-malignant tissue adjacent to the tumour; this in order to specifically evaluate the responsiveness of the cell types obtained from the same patients. We demonstrated here that, in breast cancer cells, BK stimulated cell proliferation through the $\mathrm{B}_{2}$ receptor; the proliferative effects of $\mathrm{BK}$ was higher in tumour with respect to peritumour cells (Fig. 3).

It is known that MAPK is a key signal-transducing protein which transmits signals involved in cell proliferation, and BK has been found to elicit mitogenic responses through the activation of MEK/MAPK pathways in other cell types (Velarde et al. 1999, Luo et al. 2000), including normal epithelial breast cells (Greco et al. 2004). We have here confirmed that the proliferation of epithelial breast cancer cells was also sustained by ERK1/2 activation (Fig. 7). Upstream regulators of MAPK, such as the oncogene products ras (Janes et al. 1994) and Raf-1 (Callans et al. 1995), as well as PKC (Arteaga et al. 1991), have been associated with breast cancer. Most of the biological actions of the $B_{2}$ receptor are mediated via $G_{q / 11}$ protein leading to an increase in $\left[\mathrm{Ca}^{2+}\right]_{\mathrm{i}}$ and PKC activation in different cell types (Enomoto et al. 1995, Ankorina-Stark et al. 1997, Wiernas et al. 1998). In breast cells, BK induced a $\left[\mathrm{Ca}^{2+}\right]_{\mathrm{i}}$ increase higher in tumour than in peritumour cells (Fig. 2). $\mathrm{Ca}^{2+}$ is an important mediator of the expression of immediate early genes such as c-fos, c-jun and $\mathrm{c}-m y c$ involved in the regulation of cell proliferation (Curran \& Morgan 1987, Ransone \& Verma 1990). Nevertheless, in tumour, peritumour and normal cells (Greco et al. 2004) the BK-dependent $\mathrm{Ca}^{2+}$-dependent PKCs were not responsible for the mitogenic stimulus of BK, since their inhibition by Gö6976 did not affect the proliferative effect of BK (Fig. 6). On the other hand, $\left[\mathrm{Ca}^{2+}\right]_{\mathrm{i}}$ regulated the Ang II-provoked proliferation of breast tumour cells in primary culture (Greco et al. 2003). These discrepancies could be explained by the different kinetics between the PKC activation provoked by Ang II and $\mathrm{BK}$; actually, Ang II stimulated translocation of PKC $-\alpha$ and $-\beta$ isozymes at $25 \mathrm{~min}$, whereas BK did so at 5 min (Fig. 5). However, in the mitogenic effects of BK, the contribution of PLC was demonstrated by U73122 (Fig. 4). As a result of $\left[\mathrm{Ca}^{2+}\right]_{\mathrm{i}}$ increase and PLC activation, the $\mathrm{B}_{2}$ receptor provoked the translocation from the cytosol to the membrane of five PKC isozymes (PKC- $\alpha$, $-\beta,-\delta,-\varepsilon$ and $-\eta$ ) in tumour cells (Fig. 5).

In conclusion, this study has shown for the first time that BK has mitogenic effects in epithelial breast cancer cells and in the normal peritumour cells in primary culture. It has been shown that kinins are able to increase vascular permeability and cell proliferation, thus facilitating tumour metastasis (Robert \& Gulick 1989, Marceau 1995). Moreover, after infiltration in normal adjacent tissues, many tumour cells can chemotactically attract inflammatory cells (Dlamini et al. 1999) thereby regulating angiogenesis (Plendl et al. 2000). In this regard, BK represents an influential mitogenic agent in normal breast glandular tissue, whose effects are also retained in peritumour and tumour cells. Hence, it is likely that BK has an important role in cancer endorsement and progression.

\section{Acknowledgements}

We are grateful to the Italian MIUR for project grant support (Ricerca di Base). We also would like to thank M Giuseppe A Pede for skilful technical assistance. The authors declare that there is no conflict of interest that would prejudice the impartiality of this scientific work.

\section{References}

Alessi DR, Cuenda A, Cohen P, Dudley DT \& Saltiel AR 1995 PD 098059 is a specific inhibitor of the activation of mitogen-activated protein kinase kinase in vitro and in vivo. Journal of Biological Chemistry 270 27489-27494.

Ankorina-Stark I, Haxelmans S \& Schlatter E 1997 Receptors for bradykinin and prostaglandin $\mathrm{E} 2$ coupled to $\mathrm{Ca}^{2+}$ signalling in rat cortical collecting duct. Cell Calcium 22 269-275.

Arteaga CL, Johnson MD, Todderud G, Coffey RJ, Carpenter G \& Page DL 1991 Elevated content of the tyrosine kinase substrate phospholipase C-gamma 1 in primary human breast carcinomas. PNAS 88 10435-10439. 
Biscardi JS, Ishizawar RC, Silva CM \& Parsons SJ 2000 Tyrosine kinase signalling in breast cancer: epidermal growth factor receptor and $\mathrm{c}-\mathrm{Src}$ interactions in breast cancer. Breast Cancer Research 2 203-210.

Blackburn AC \& Jerry DJ 2002 Knockout and transgenic mice of Trp53: what have we learned about p53 in breast cancer? Breast Cancer Research 4 101-111.

Callans LS, Naama H, Khandelwal M, Plotkin R \& Jardines L 1995 Raf-1 protein expression in human breast cancer cells. Annals of Surgical Oncology 2 38-42.

Chen YP, Chao J \& Chao L 1988 Molecular cloning and characterisation of two rat renal kallikrein genes. Biochemistry 27 7189-7196.

Clements JA 1997 The molecular biology of the kallikreins and their roles in inflammation. In The Kinin System, pp 71-97. Ed. SG Farmer. London: Academic Press.

Clements J \& Mukhtar A 1977 Tissue kallikrein and the bradykinin B2 receptor are expressed in endometrial and prostate cancers. Immunopharmacology 36 217-220.

Curran T \& Morgan JI 1987 Memories of fos. Bioessays 7 255-258.

el-Dahr SS, Figueroa CD, Gonzalez CB \& Muller-Esterl W 1997 Ontogeny of bradykinin B2 receptors in the rat kidney: implications for segmental nephron maturation. Kidney International 51 739-749.

Descamps S, Lebourhis X, Delehedde M, Boilly B \& Hondermarck H 1998 Nerve growth factor is mitogenic for tumoural but not for normal human epithelial cells. Journal of Biological Chemistry 273 16659-16662.

Dlamini Z, Raidoo D \& Bhoola K 1999 Visualisation of tissue kallikrein and kinin receptors in oesophageal carcinoma. Immunopharmacology 43 303-310.

Drube S \& Liebmann C 2000 In varoius tumour cell lines the peptide bradykinin B2 receptor antagonist, Hoe 140 (Icatibant), may act as mitogenic agonist. British Journal of Pharmacology 131 1553-1560.

Dupont J \& Le Roith D 2001 Insulin-like growth factor 1 and oestradiol promote cell proliferation of MCF-7 breast cancer cells: new insights into their synergistic effects. Molecular Pathology 54 149-154.

Enomoto K, Furuya K, Yamagishi S, Oka T \& Maeno T 1995 Release of arachidonic acid via $\mathrm{Ca}^{2+}$ increase stimulated by pyrophosphonucelotides and bradykinin in mammary tumour cells. Cell Biochemistry and Function 13 279-286.

Ethier SP 1995 Growth factor synthesis and human breast cancer progression. Journal of the National Cancer Institute 87 964-973.

Greco S, Elia MG, Muscella A, Storelli C \& Marsigliante S 2002a AT1 Angiotensin II receptor mediates intracellular calcium mobilization in normal and tumoural breast cells in primary culture. Cell Calcium 32 1-10.

Greco S, Muscella A, Elia MG, Salvatore P, Storelli C \& Marsigliante S $2002 b$ Activation of angiotensin II type I receptor promotes protein kinase $\mathrm{C}$ translocation and cell proliferation in human cultured breast epithelial cells. Journal of Endocrinology 174 205-214.

Greco S, Muscella A, Elia MG, Salvatore P, Storelli C, Mazzotta A, Manca C \& Marsigliante S 2003 Angiotensin II activates extracellular signal regulated kinases via protein kinase $\mathrm{C}$ and epidermal growth factor receptor in breast cancer cells. Journal of Cellular Physiology 196 370-377.

Greco S, Muscella A, Elia MG, Romano S, Storelli C \& Marsigliante S 2004 Mitogenic signalling by B2 bradykinin receptor in epithelial breast cells. Journal of Cell Physiology 201 84-96.

Grynkiewicz G, Poenie M \& Tsien RY 1985 A new generation of $\mathrm{Ca}^{2+}$ indicators with greatly improved fluorescence properties. Journal of Biological Chemistry $2603440-3450$.

Harris RE, Namboodiri KK \& Wynder EL 1992 Breast cancer risk: effects of estrogen replacement therapy and body mass. Journal of the National Cancer Institute 84 1575-1582.

Harris RE, Chlebowski RT, Jackson RD, Frid DJ, Ascenseo JL, Anderson G, Loar A, Rodabough RJ, White E \& McTiernan A
2003 Breast cancer and nonsteroidal anti-inflammatory drugs: prospective results from the Women's Health Initiative. Cancer Research 63 6096-6101.

Henderson IC 1993 Risk factors for breast cancer development. Cancer 71 2127-2140.

Henson DE \& Tarone RE 1994 Involution and the etiology of breast cancer. Cancer 74 424-429.

Hermann A, Buchinger P \& Rehbock J 1995 Visualization of tissue kallikrein in human breast carcinoma by two-dimensional Western blotting and immunohistochemistry. Biological Chemistry Hoppe-Seyler 376 365-370.

Janes PW, Daly RJ, deFazio A \& Sutherland RL 1994 Activation of the Ras signalling pathway in human breast cancer cells overexpressing erbB-2. Oncogene 9 3601-3608.

Jones TH, Figueroa CD, Smith C, Cullen DR \& Bhoola KD 1992 Tissue kallikrein is associated with prolactin-secreting cells within human growth hormone secreting adenomas. Journal of Endocrinology 134 149-154.

Koshikawa N, Yasumitsu H, Umeda M \& Miyazaki K 1992 Multiple secretion of matrix serine proteinases by human gastric carcinoma cell lines. Cancer Research 52 5046-5053.

Luo SF, Wang CC, Chiu CT, Chien CS, Hsiao LD, Lin CH \& Yang CM 2000 Lipopolysaccharide enhances bradykinin-induced signal transduction via activation of Ras/Raf/MEK/MAPK in canine tracheal smooth muscle cells. British Journal of Pharmacology 130 1799-1808.

Ma JX, Wang DZ, Ward DC, Chen L, Dessai T, Chao J \& Chao L 1994 Structure and chromosomal localisation of gene (BDKRB2) encoding the bradykinin B2 receptor. Genomics 23 362-369.

Maeda H, Wu J, Okamoto T, Maruo K \& Akaike T 1999 Kallikrein kinin in infection and cancer. Immunopharmacology 43 115-128.

Marceau F 1995 Kinin B1 receptors: a review. Immunopharmacology 30 $1-26$.

Michie C, Lockie F \& Lynn W 2003 The challenge of mastitis. Archives of Diseases in Childhood 88 818-821.

Norby JG 1988 Coupled assay of $\mathrm{Na}^{+}, \mathrm{K}^{+}$-ATPase activity. In Methods in Enzymology 156 116-119.

Nurcombe V, Smart CE, Chipperfield H, Cool SM, Boilly B \& Hondermarck H 2000 The proliferative and migratory activities of breast cancer cells can be differentially regulated by heparan sulfates. Journal of Biological Chemistry 275 30009-30018.

Pesquero JB \& Bader M 1998 Molecular biology of the kallikrein-kinin system: from structure to function. Brazilian Journal of Medical and Biological Research 31 1197-1203.

Plendl J, Snyman C, Naidoo S, Sawant S, Mahabeer R \& Bhoola KD 2000 Expression of tissue kallikrein and kinin receptors in angiogenic microvascular endothelial cells. Biological Chemistry 38 1103-1115.

Portier CJ 2002 Endocrine dismodulation and cancer. Neuroendocrinology Letters 2 43-47.

Randolph JB \& Waggoner AS 1997 Stability, specificity and fluorescence brightness of multiply-labeled fluorescent DNA probes. Nucleic Acid Research 25 2923-2929.

Ransone LJ \& Verma IM 1990 Nuclear proto-oncogenes fos and jun. Annual Review of Cell Biology 6 539-557.

Regoli D \& Barabé J 1980 Pharmacology of bradykinin and related peptides. Pharmacological Reviews 32 1-46.

Rehbock J, Buchinger P, Hermann A \& Figueroa C 1995 Identification of immunoreactive tissue kallikrein in human ductal breast carcinomas. Journal of Cancer Research and Clinical Oncology 121 64-68.

Robert RM \& Gulick WJ 1989 Bradykinin receptor number and sensitivity to ligand stimulation of mitogenesis by expression of mutant ras oncogene. Journal of Cell Science 94 527-535.

Sachdev D \& Yee D 2001 The IGF system and breast cancer. Endocrine-Related Cancer 8 197-209.

Stewart JM 2003 Bradykinin antagonists as anti-cancer agents. Current Pharmaceutical Design 9 2036-2042. 
Vavrek R \& Stewart JM 1985 Competitive antagonists of bradykinin. Peptides 6 161-164.

Velarde V, Ullian ME, Morinelli TA, Mayfield RK \& Jaffa AA 1999 Mechanisms of MAPK activation by bradykinin in vascular smooth muscle cells. American Journal of Physiology - Cell Physiology 277 C253-C261.

Venkitaraman AR 2002 Cancer susceptibility and the functions of BRCA1 and BRCA2. Cell 108 171-182.

Wakefield LM, Piek E \& Bottinger EP 2001 TGF-beta signaling in mammary gland development and tumorigenesis. Journal of Mammary Gland Biology and Neoplasia 6 67-82.

Wiernas TK, Davis TL, Griffin BW \& Sharif NA 1998 Effects of bradykinin on signal transduction, cell proliferation, and cytokine, prostaglandin E2 and collagenase-1 release from human corneal epithelial cells. British Journal of Pharmacology 123 1127-1137.
Xing C \& Imagawa W 1999 Altered MAP kinase (ERK1,2) regulation in primary cultures of mammary tumor cells: elevated basal activity and sustained response to EGF. Carcinogenesis 20 1201-1208.

Yu H, Bowden DW, Spray BJ, Rich SS \& Freedman BI 1998 Identification of human plasma kallikrein gene polymorphisms and evaluation of their role in end-stage renal disease. Hypertension 31 906-911.

Received in final form 12 April 2005

Accepted 20 May 2005

Made available online as as Accepted Preprint 10 June 2005 